Published in final edited form as:

J Allergy Clin Immunol Pract. 2016 ; 4(4): 565-572. doi:10.1016/j.jaip.2016.04.012.

\title{
Chronic Rhinosinusitis with Nasal Polyps
}

\author{
Whitney W. Stevens, MD, PhD ${ }^{1}$, Robert P. Schleimer, PhD $^{1,2}$, and Robert C. Kern, MD $^{2}$ \\ ${ }^{1}$ Division of Allergy-Immunology, Department of Medicine, Northwestern University Feinberg \\ School of Medicine, Chicago, IL USA \\ ${ }^{2}$ Department of Otolaryngology, Northwestern University Feinberg School of Medicine, Chicago, \\ IL, USA
}

\begin{abstract}
Chronic rhinosinusitis with nasal polyps (CRSwNP) is an important clinical entity diagnosed by the presence of both subjective and objective evidence of chronic sinonasal inflammation. Symptoms include anterior or posterior rhinorrhea, nasal congestion, hyposmia and/or facial pressure or pain that last for greater than 12 weeks duration. Nasal polyps are inflammatory lesions that project into the nasal airway, are typically bilateral, and originate from the ethmoid sinus. Males are more likely to be affected than females but no specific genetic or environmental factors have been strongly linked to the development of this disorder to date. CRSwNP is frequently associated with asthma and allergic rhinitis but the cellular and molecular mechanisms that contribute to the clinical symptoms are not fully understood. Defects in the sinonasal epithelial cell barrier, increased exposure to pathogenic and colonized bacteria, and dysregulation of the host immune system are all thought to play prominent roles in disease pathogenesis. Additional studies are needed to further explore the clinical and pathophysiological features of CRSwNP so that biomarkers can be identified and novel advances can be made to improve the treatment and management of this disease.
\end{abstract}

\section{Keywords}

Chronic rhinosinusitis with nasal polyps; Nasal polyp; Chronic rhinosinusitis

\section{Introduction}

\begin{abstract}
Nasal polyps are inflammatory outgrowths of sinonasal tissue that are estimated to occur in $1-4 \%$ of the US general population ${ }^{1}$. While nasal polyps are observed in a variety of clinical conditions including cystic fibrosis and malignancy, they are more frequently associated with a subset of chronic rhinosinusitis aptly named chronic rhinosinusitis with
\end{abstract}

Corresponding author: Dr. Whitney Stevens, Division of Allergy-Immunology, Northwestern University Feinberg School of Medicine, 211 E. Ontario Street Suite 1000, Chicago, Illinois 60611, USA, Tel.: 312.695.4000, Fax: 312.695.4141, whitneystevens@northwestern.edu.

Publisher's Disclaimer: This is a PDF file of an unedited manuscript that has been accepted for publication. As a service to our customers we are providing this early version of the manuscript. The manuscript will undergo copyediting, typesetting, and review of the resulting proof before it is published in its final citable form. Please note that during the production process errors may be discovered which could affect the content, and all legal disclaimers that apply to the journal pertain. 
nasal polyps (CRSwNP). In this condition, nasal polyps are benign and typically develop bilaterally in the sinonasal cavity. Among all patients with chronic rhinosinusitis (CRS), only $\sim 25-30 \%$ have CRSwNP. However, CRSwNP is associated with significant morbidity and decreased quality of life making this disease clinically important to identify, evaluate, and treat.

\section{Demographics}

CRSwNP is a disease of middle age with the average age of onset being 42 years and the typical age of diagnosis ranging from $40-60$ years ${ }^{1,2}$. Most commonly, nasal polyps present as bilateral inflammatory lesions originating in the ethmoid sinuses and projecting into the nasal airway beneath the middle turbinate. In contrast, isolated nasal lesions that present medial to the middle turbinate are concerning for neoplasm. Presumptive nasal polyps found in patients less than 20 years or greater than 80 years also raise suspicion for other clinical conditions. In children, cystic fibrosis becomes a concern ${ }^{34}$ and unilateral nasal growths suggest a possible encephalocele. In adults, new onset polyps at an advanced age or in atypical locations suggest the possibility of neoplasm.

Males are more likely to have CRSwNP than females ${ }^{1}$. However, a 2015 study by Stevens and colleagues examining CRSwNP patients undergoing sinus surgery at a tertiary care center found that females with CRSwNP had more severe disease than males ${ }^{5}$. In this study, CRSwNP was diagnosed in $38 \%$ and $62 \%$ of females and males respectively. When compared to males, females had significantly enhanced radiographic evidence of sinus disease, were more likely to be taking systemic corticosteroids at the time of sinus surgery, and more often required revision sinus surgeries ${ }^{5}$. Additional studies are needed to better understand the underlying pathophysiological and societal factors that could be contributing to these observations.

\section{Clinical Characteristics}

By definition, patients with CRSwNP must report the presence of anterior or posterior rhinorrhea, nasal congestion, hyposmia and/or facial pressure or pain lasting for greater than 12 weeks duration ${ }^{1}$. However, these subjective findings are neither sensitive nor specific for CRSwNP alone and are used to also characterize patients who have chronic rhinosinusitis without nasal polyps (CRSsNP) ${ }^{1}$. On average, CRSwNP patients are thought to have more severe sinonasal symptoms than CRSsNP patients ${ }^{6,7}$.

To improve the ability to clinically distinguish CRSwNP from CRSsNP, several studies have compared symptom profiles of affected patients as a means to identify possible clinical factors unique to each condition. In a cohort of 126 CRS patients, Banjeri and colleagues found that nasal obstruction and hyposmia/anosmia were more significantly associated with CRSwNP while facial pain/pressure was more prevalent in CRSsNP patients ${ }^{8}$. Additional studies of CRS patients at separate tertiary care centers found CRSwNP patients were more likely to report rhinorrhea, severe nasal congestion and loss of smell/taste than patients with CRSsNP ${ }^{9,10}$. However, in both studies, there was still a considerable overlap in symptoms 
reported by both CRSsNP and CRSwNP patients, thus emphasizing the need for additional criteria to diagnose CRSwNP.

In addition to subjective assessments of CRSwNP, there must be objective evidence of sinonasal inflammation and nasal polyps on sinus CT scan and/or nasal endoscopy (Figure 1). Patients with CRSwNP on average have more extensive sinus disease than CRSsNP patients as measured by worse sinus $\mathrm{CT}$ and endoscopic scores ${ }^{1178}$. Even following sinus surgery, patients with CRSwNP can continue to have more severe objective measures of sinus disease than CRSsNP patients who also underwent surgery 6,12 . It is thus not surprising that patients with CRSwNP on average are more likely to require revision sinus surgeries than CRSsNP patients ${ }^{6}$.

\section{Comorbidities}

CRSwNP is often associated with other important medical conditions that can influence disease severity. In a large retrospective study evaluating over 400,000 primary care patients, those diagnosed with CRSwNP had a significantly higher premorbid prevalence of acute rhinosinusitis, allergic rhinitis, chronic rhinitis, asthma, gastroesophageal reflux disease, and sleep apnea ${ }^{13}$. How these conditions could contribute to the development of CRSwNP remains unclear.

The role of atopy in CRSwNP has been the focus of numerous studies. While the percent of allergic rhinitis patients with nasal polyps is similar to that of the general population (0.5$4.5 \%)^{1}, 51-86 \%$ of CRSwNP patients are sensitized to at least one aeroallergen ${ }^{1114}$. No study to date has established a relationship between sensitization by one particular aeroallergen and the development of CRSwNP, but sinus disease can worsen during allergen season ${ }^{15}$

Further complicating the understanding of CRSwNP are conflicting reports regarding the relationship between atopy and sinus disease severity. Some studies report that sinus CT and endoscopic scores are significantly worse in patients sensitized to inhalant allergens ${ }^{11,16}$ while other studies found no difference in sinus severity in sensitized and non atopic patients ${ }^{14,1715}$. In summary, future investigations are needed to better explore how atopy may contribute to CRSwNP.

The association between asthma and CRSwNP has been more extensively defined. A large majority of asthmatics $(\sim 88 \%)$ have at least some radiographic evidence of sinonasal inflammation ${ }^{1}$. More specifically, CRSwNP is estimated to occur in $7 \%$ of all asthmatics while asthma is reported in $26-48 \%$ of patients with CRSwNP ${ }^{1,18}$. Pearlman and colleagues found the prevalence of nasal polyps to be significantly greater in asthmatics compared to non-asthmatics within a tertiary care population ${ }^{15}$. Additionally, CRSwNP patients were more likely to have asthma than patients with CRSsNP, odds ratio of 7.5 ${ }^{1911}$. Increased asthma severity has also been shown to be associated with enhanced sinonasal inflammation ${ }^{20}$.

There is a subset of patients with CRSwNP and asthma who also develop upper and/or lower respiratory tract symptoms following the ingestion of medications that inhibit the 
cycloygenase-1 (COX-1) enzyme. Such patients have Aspirin Exacerbated Respiratory Disease (AERD). It is estimated that $10 \%$ of patients with nasal polyps and $9 \%$ of patients with CRS have AERD ${ }^{21}$ but the true prevalence of this disease remains unknown. Furthermore, AERD patients on average have more severe sinus disease and undergo more sinus surgeries than patients with CRSwNP alone ${ }^{22}$. There have been several important studies characterizing the clinical profiles of patients with AERD as well as defining unique underlying mechanisms in disease pathology 23,24 . As such, AERD will not be further discussed in this review.

\section{Pathophysiology}

The underlying mechanisms that contribute to the chronic sinonasal inflammation observed in CRSwNP are not completely defined. Various research groups have focused on exploring the role sinonasal epithelial cells, the host immune system, and pathogens may play in CRSwNP pathogenesis (Figure 2). It is hypothesized that an impaired sinonasal epithelial barrier could lead to increased exposures to inhaled pathogens, antigens and particulates that, in the setting of a dysregulated host immune response, could promote chronic inflammation.

In healthy conditions, the epithelial cells which line the sinonasal mucosa not only form a physical barrier to protect the host from inhaled respiratory pathogens and particulates but also play critical roles in mucociliary clearance and host defense. In CRSwNP, the sinonasal epithelial barrier is defective leading to increased tissue permeability, decreased epithelial resistance, acanthosis, and acantholysis. Why the epithelial barrier is defective in CRSwNP remains unclear. It may be that epithelial cells are inherently abnormal in CRSwNP ${ }^{25}$. Alternatively, extrinsic factors unique to CRSwNP could impair an otherwise intact epithelial barrier and induce the breakdown observed in CRSwNP. To this end, Pothoven and colleagues noted that oncostatin M, a IL-6 family member, was elevated in CRSwNP nasal polyps and could induce tissue permeability, disrupt tight junctions, and decrease electrical resistance in cultured human epithelial cells ${ }^{26}$.

Other aspects of epithelial host defense are also impaired in CRSwNP. For example, levels of epithelial-derived antimicrobial proteins including lysozyme, S100A7, S100A8/9, betadefensins, and Palate, Lung, and Nasal Epithelial Clone (PLUNC) proteins were reduced in CRSwNP patients compared to healthy controls $2728-30$. Pendrin, an epithelial ion transporter that can increase mucus production, and Muc5AC, a type of mucin, were elevated in CRSwNP versus controls ${ }^{3132}$. These findings suggest that impairment in mucociliary clearance, reduction in antimicrobial defense protein secretion, and breakdown in the physical barrier can lead to chronic exposure of pathogenic and non-pathogenic mediators and the development of a chronic inflammatory response.

The dysregulation of the host immune system has also been extensively evaluated in CRSwNP. Originally, this disease was categorized by a type- 2 inflammatory response with enhanced tissue eosinophilia. Levels of eosinophilic granule proteins (e.g. eosinophil cationic protein (ECP)), the eosinophilic survival factor (IL-5), and eosinophil chemotactic proteins (e.g. Eotaxin-1, Eotaxin-2, Eotaxin-3, MCP-4) are all elevated in CRSwNP nasal 
polyps compared to healthy controls ${ }^{33-38}$. Studies have also reported CRSwNP to have increased numbers of basophils ${ }^{39}$, innate type- 2 lymphoid cells ${ }^{40}$ and mast cells ${ }^{41}$. Additionally, type- 2 cytokines including IL-5 and IL-13 ${ }^{36}$ as well as the epithelial cellderived thymic stromal lymphopoietin (TSLP) ${ }^{42}$ are elevated in CRSwNP. While the inflammatory environment in CRSwNP has been extensively characterized, the specific events and signals that initiate this response are not well defined.

Further complicating the study of CRSwNP pathogenesis is the observation that not all nasal polyps have the same histological appearance. The original studies of type- 2 inflammation and nasal polyps were completed in CRSwNP patients of European descent. However, a paper published in 2008 indicated that nasal polyps of Asian patients living in Asia lack enhanced tissue eosinophilia, have lower levels of IL-5, and increased levels of the type-1 cytokine IFN- $\gamma$ when compared to nasal polyps from European patients ${ }^{43}$. As a result, genetic factors may also be contributing to CRSwNP pathology as discussed below.

In addition to innate immune response, the host adaptive immune system is also dysregulated in CRSwNP. Naive B cells and activated plasma cells are elevated in nasal polyps compared to healthy controls ${ }^{44-46}$. This is most likely in response to nasal polyps also having increased levels of CXCL-12 and CXCL-13 (factors important for B cell chemotaxis) as well as BAFF and IL-6 (factors that induce B cell proliferation and activation) ${ }^{46,4748}$. Levels of $\operatorname{IgG} 1, \operatorname{IgG} 2, \operatorname{IgG} 4, \operatorname{IgA}, \operatorname{IgE}$ and $\operatorname{IgM}$ are increased in nasal polyps but not in the circulation of patients with CRSwNP suggesting that local factors within the nasal polyp can activate B cells ${ }^{45}$. The exact specificity of the antibodies detected in CRSwNP remains unclear but is the focus of ongoing investigations. Studies have provided evidence that some of the antibodies detected in CRSwNP polyps are directed against nuclear antigens and cytokines ${ }^{4950}$. How such autoantibodies contribute to the clinical symptoms of CRSwNP remains unclear.

The adaptive immune system is also comprised of $\mathrm{T}$ cells that are important not only for their direct cytotoxic functions but also for their ability to mediate an ongoing immune response. In nasal polyps from European patients, a significant fraction of CD4 T cells can produce type- 2 cytokines compared to controls, while $\mathrm{T}$ cells isolated from nasal polyps from Asian patients are more likely to release type-1 and type-17 inflammatory mediators 38,43 . Some studies suggest that $\mathrm{T}$ regulatory cells are impaired in CRSwNP as determined by reduced levels of the transcription factor Foxp3 and increased levels of SOCS3, a known negative regulator of Foxp3 expression ${ }^{36,51}$. This imbalance in $\mathrm{T}$ regulatory cells could lead to a subsequent lack of immune suppression that in turn could promote the chronic inflammation seen in CRSwNP. However, more research is indicated in this area especially since a study published in 2014 reports that $\mathrm{T}$ regulatory cells are increased in nasal polyps ${ }^{52}$.

Finally, pathogens can directly and indirectly contribute to CRSwNP pathogenesis. Both Pseudomonas aeruginosa and Staphylococcus aureus disrupt the epithelial barrier in cultured human nasal epithelial cells ${ }^{5354}$. This impaired barrier could lead to heightened exposure to pathogens as well as increased bacterial colonization. To this end, it is estimated that as many as 63\% of CRSwNP patients are colonized with Staphylococcus aureus and a subset of 
these patients can develop specific IgE antibodies against Staphylococcus aureus enterotoxins ${ }^{55}$. Levels of specific IgE significantly correlate with levels of IL-5 and total number of eosinophils in nasal polyps suggesting these antibodies may be important in driving pathogenesis 56 .

The sinonasal cavity has a mixture of pathogenic and commensal bacterial and the properties of this microbiome have been explored in CRS, but not specifically in CRSwNP. To date, a reduced diversity of bacteria has been reported in CRS patients compared to healthy controls but no specific organism has yet been linked to causing CRS ${ }^{5758}$. Additionally, traditional pathogenic microbes including Streptococcus pneumoniae, Haemophilus influenzae, and Moraxella catarrhalis have been found in sinonasal cavities of patients without CRS, thus obscuring the role these organisms may play in disease ${ }^{59}$. Therefore, further investigations are necessary to fully characterize and define the role of pathogenic and commensal bacteria in CRSwNP.

\section{Genetics}

Given the clinical heterogeneity of CRSwNP, the genetics of this disease are not well understood. A 2015 study indicates that first-degree relatives of a patient with CRSwNP have a 4.1 -fold increased risk of developing nasal polyps ${ }^{60}$. However, no single polymorphism or genetic mutation has been consistently or reproducibly associated with CRSwNP to date with the exception of the CFTR mutation in cystic fibrosis ${ }^{61}$. For example, filaggrin mutations have been associated with other atopic diseases with epithelial barrier dysfunction including atopic dermatitis and asthma. However, a recent study found no association between presence of a common filaggrin null mutation and CRSwNP ${ }^{62}$.

It is tempting to speculate that there is some currently unidentified genetic element responsible for the histologic differences observed between nasal polyps from Asian and Western patients. In support of this concept, a study found that second-generation Asian patients living in the US still had reduced nasal polyp eosinophilia compared to Caucasian or African American patients within the same surgical cohort ${ }^{63}$. However, prospective studies in Asia have suggested that the prevalence of eosinophils in nasal polyps is increasing especially in urban areas ${ }^{6465}$. Taken together, the development of CRSwNP may be dependent on both a genetic predisposition and exposure to specific albeit unclear environmental factors.

\section{Biomarkers}

There is no single validated biomarker that can reliably predict if a patient has CRSwNP versus CRSsNP, acute sinusitis, or no sinus disease at all. Eosinophil markers such as ECP, IL-5, or Eotaxin may be useful in confirming CRSwNP but not all CRSwNP patients will have elevated type- 2 inflammatory markers and vice versa. There are no biomarkers to date that predict who will respond to medical versus surgical treatment. However, Lou and colleagues reported that having an absolute tissue eosinophil count $>55$ eosinophils per high power field or having more than $27 \%$ eosinophils out of the entire cells counted in a 
sinonasal tissue specimen predicted the recurrence of nasal polyps within 2 years of sinus surgery 66 .

When seeking a biomarker, it is important to consider the clinical specimen from which it will be measured. Peripheral blood, while easy to obtain, may not reflect the inflammatory changes observed locally in nasal polyps. A recent study examined if there was a direct correlation between levels of inflammatory mediators measured in nasal lavage fluid versus nasal polyp tissue within the same individuals. Of the 20 mediators evaluated (including ECP, IL-5, IL-13, and eotaxin) only IL-10 was found to have a significant and positive correlation between nasal lavage and polyp tissue ${ }^{37}$. This finding supports a prior observation that there is regional variability in inflammatory mediator expression within a single sinonasal cavity ${ }^{67}$. Therefore, the chronic inflammation in nasal polyps may not necessarily be reflected when sampling the entire nasal cavity by lavage.

\section{Definition of CRS}

According to the EPOS 2012 guidelines, CRS is defined as inflammation of the nose and paranasal sinuses characterized by the presence of two or more of the following symptoms for greater than 12 weeks duration: 1) nasal blockage/obstruction/congestion; 2) nasal discharge; 3) facial pain/pressure; 4) reduction or loss of smell ${ }^{1}$. Objective confirmation of the diagnosis is made by sinus CT scan or nasal endoscopy that will also determine the phenotype: CRSsNP or CRSwNP. In adults, nasal polyps should be seen in both nasal passages and any unilateral polyps should be concerning for an alternative etiology such as malignancy.

\section{Recommendation for information to be obtained to determine the phenotype}

When evaluating patients for CRSwNP, it is important to evaluate for the presence of the 4 cardinal symptoms: rhinorrhea, nasal congestion, facial pressure/pain, and hyposmia. While not definitive, hyposmia is more classically associated with CRSwNP while facial pain/ pressure is more suggestive of CRSsNP ${ }^{8,9}$. It remains difficult to distinguish eosinophilic and non-eosinophilic nasal polyps by clinical symptoms alone. A recent study examining 57 CRS patients who underwent surgery at a tertiary care facility found that ear pain, sneezing, severe difficulty breathing through the nose, severe nasal congestion, and bothersome loss of taste/smell were significantly more likely to be reported in patients with eosinophilic compared to non-eosinophilic nasal polyps ${ }^{10}$. The duration of sinus symptoms is also critical to ascertain, as symptoms lasting greater than 12 weeks are consistent with chronic rhinosinusitis while those lasting less than 4 weeks are more concerning for an acute infectious process.

In addition to addressing sinonasal complaints, a detailed clinical history should be obtained to establish the presence of an underlying lower respiratory disease such as asthma. Past reactions to any COX-1 inhibitors should be documented so as to not miss the diagnosis of AERD. Finally, symptoms such as sneezing, itching, and ocular involvement are suggestive for underlying allergic rhinitis and should be evaluated given the association with CRSwNP. 


\section{Treatment}

Medical treatment options for patients with CRSwNP remain limited. According to the most recent US guidelines, both topical corticosteroids and nasal saline irrigations are recommended as initial medical therapies for affected patients ${ }^{68}$. Intranasal corticosteroids can decrease nasal polyp size, lessen sinonasal symptoms, and improve patient quality of life ${ }^{6970}$. Oral corticosteroids can also reduce polyp size and improve symptoms but should always be administered cautiously given their association with serious systemic side effects ${ }^{71}$. Antibiotics may be useful in treating infectious exacerbations of CRSwNP, but clinically significant efficacy (i.e., polyp shrinkage) in large, randomized trials is lacking.

Patients with significant sinonasal disease and/or those who fail medical management should be evaluated for sinus surgery. In a retrospective analysis, a delay in over 5 years from initial CRS diagnosis to sinus surgery was associated with greater post-operative health care utilization compared to when surgery was performed within 12 months of diagnosis ${ }^{72}$. Functional endoscopic sinus surgery can improve sinonasal symptoms as well as objective evidence of sinonasal inflammation on sinus CT scan ${ }^{2273}$. However, nasal polyps can still reoccur despite sinus surgery ${ }^{74}$ with patients having both CRSwNP and asthma requiring, on average, significantly more sinus surgeries than patients with CRSwNP alone ${ }^{75}$.

In 2011, the US Food and Drug Administration approved the use of Propel ${ }^{\mathrm{TM}}$ implants, biodegradable stents that elute mometasone over a 30-day period ${ }^{76-78}$. When inserted at the time of sinus surgery, these stents significantly reduced postoperative surgical interventions by $51 \%$, oral corticosteroid use by $40 \%$, and frank nasal polyposis by $46 \%{ }^{79}$ after 1 month. Given these findings, a longer-lasting variant of Propel ${ }^{\mathrm{TM}}$ is currently being evaluated in a FDA trial with initial results suggesting this stent can significantly improve polyp size and nasal symptoms 3 months following insertion ${ }^{80}$.

There have also been several promising clinical trials evaluating the safety and efficacy of various biologics in CRSwNP. Notably, these drugs target factors associated with the type-2 inflammation observed in the polyp tissue. Omalizumab, a fully humanized anti-IgE monoclonal antibody, significantly reduced nasal polyp size and improved symptoms when compared to placebo in CRSwNP patients independent of atopic status ${ }^{81}$. In CRSwNP patients with severe nasal polyposis refractory to corticosteroid therapy, mepolizumab, a humanized anti-IL-5 antibody, also significantly reduced nasal polyps and improved sense of smell, post-nasal drip, and nasal congestion (but not rhinorrhea) when compared to placebo treated controls ${ }^{82}$. Finally, dupilumab, a human monoclonal antibody that binds to the IL-4 receptor alpha subunit and inhibits signaling of IL-4 and IL-13, significantly reduced nasal polyp burden and improved nasal symptoms when used in conjunction with intranasal steroids in CRSwNP patients with refractory disease ${ }^{83}$. It should be noted that omalizumab, mepolizumab, and dupilumab are currently not approved for the treatment of nasal polyps. However, given the separate observations that omalizumab, mepolizumab, and dupilumab can also reduce asthma exacerbations ${ }^{84-86}$, it is possible that these biological agents could have potentially even greater beneficial effects in patients with both asthma and CRSwNP. 


\section{Research questions and future directions}

Over the past decade, there have been very important advances made in both the clinical and pathophysiological understanding of CRSwNP. However, many important questions still remain unanswered including:

- What is the true prevalence of CRSwNP within the general population or even among patients with CRS with or without asthma?

- What are the factors (environmental or genetic) that trigger the development of CRSwNP?

- What role does bacteria (pathogenic or commensurate) play in CRSwNP?

- What are the precise cellular and molecular events that lead to epithelial barrier dysfunction and immune dysregulation in CRSwNP?

- What are unique biomarkers in CRSwNP that could serve as targets for potential clinical and therapeutic interventions?

- What are the underlying mechanisms by which omalizumab, mepolizumab, and dupilumab exert their clinical effects?

\section{Conclusion}

In summary, CRSwNP is an important clinical entity diagnosed based upon the presence of subjective and objective evidence of chronic sinonasal inflammation. Nasal polyps occur bilaterally within the nasal cavity and are benign in CRSwNP. Men are more likely to be affected than women but no specific genetic or environmental factors have been linked to the development of the disorder to date. CRSwNP is frequently associated with asthma and allergic rhinitis but the cellular and molecular mechanisms that contribute to the clinical symptoms are not fully understood. Defects in the sinonasal epithelial cell barrier, increased exposure to pathogenic and colonizing bacteria, and dysregulation of the host immune system are all thought to play prominent roles in disease pathogenesis. Additional studies are needed to further explore the clinical and pathophysiological features of CRSwNP so that biomarkers can be identified and novel advances can be made to improve the treatment and management of this disease.

\section{Acknowledgments}

The authors wish to thank Ms. Jacqueline Schaffer for the illustration included in this review.

\section{Abbreviations}

$\begin{array}{ll}\text { ECP } & \text { Eosinophil Cationic Protein } \\ \text { CRS } & \text { Chronic rhinosinusitis } \\ \text { CRSsNP } & \text { Chronic rhinosinusitis without nasal polyps } \\ \text { CRSwNP } & \text { Chronic rhinosinusitis with nasal polyps }\end{array}$




\section{References}

1. Fokkens WJ, Lund VJ, Mullol J, Bachert C, Alobid I, Baroody F, et al. European Position Paper on Rhinosinusitis and Nasal Polyps 2012. Rhinol Suppl. 2012; 3:1-298. p preceding table of contents.

2. Grigoreas C, Vourdas D, Petalas K, Simeonidis G, Demeroutis I, Tsioulos T. Nasal polyps in patients with rhinitis and asthma. Allergy Asthma Proc. 2002; 23:169-74. [PubMed: 12125503]

3. Mainz JG, Koitschev A. Pathogenesis and management of nasal polyposis in cystic fibrosis. Curr Allergy Asthma Rep. 2012; 12:163-74.

4. Steinke JW, Payne SC, Chen PG, Negri J, Stelow EB, Borish L. Etiology of nasal polyps in cystic fibrosis: not a unimodal disease. Ann Otol Rhinol Laryngol. 2012; 121:579-86. [PubMed: 23012896]

5. Stevens WW, Peters AT, Suh L, Norton JE, Kern RC, Conley DB, et al. A retrospective, crosssectional study reveals that women with CRSwNP have more severe disease than men. Immun Inflamm Dis. 2015; 3:14-22. [PubMed: 25866636]

6. Deal RT, Kountakis SE. Significance of nasal polyps in chronic rhinosinusitis: symptoms and surgical outcomes. Laryngoscope. 2004; 114:1932-5. [PubMed: 15510016]

7. Toros SZ, Bolukbasi S, Naiboglu B, Er B, Akkaynak C, Noshari H, et al. Comparative outcomes of endoscopic sinus surgery in patients with chronic sinusitis and nasal polyps. Eur Arch Otorhinolaryngol. 2007; 264:1003-8. [PubMed: 17431658]

8. Banerji A, Piccirillo JF, Thawley SE, Levitt RG, Schechtman KB, Kramper MA, et al. Chronic rhinosinusitis patients with polyps or polypoid mucosa have a greater burden of illness. Am J Rhinol. 2007; 21:19-26. [PubMed: 17283555]

9. Dietz de Loos DA, Hopkins C, Fokkens WJ. Symptoms in chronic rhinosinusitis with and without nasal polyps. Laryngoscope. 2013; 123:57-63. [PubMed: 23280941]

10. Thompson CF, Price CP, Huang JH, Min JY, Suh LA, Shintani-Smith S, et al. A pilot study of symptom profiles from a polyp vs an eosinophilic-based classification of chronic rhinosinusitis. Int Forum Allergy Rhinol. 2015

11. Batra PS, Tong L, Citardi MJ. Analysis of comorbidities and objective parameters in refractory chronic rhinosinusitis. Laryngoscope. 2013; 123(Suppl 7):S1-11. [PubMed: 24122826]

12. Poetker DM, Mendolia-Loffredo S, Smith TL. Outcomes of endoscopic sinus surgery for chronic rhinosinusitis associated with sinonasal polyposis. Am J Rhinol. 2007; 21:84-8. [PubMed: 17283567]

13. Tan BK, Chandra RK, Pollak J, Kato A, Conley DB, Peters AT, et al. Incidence and associated premorbid diagnoses of patients with chronic rhinosinusitis. J Allergy Clin Immunol. 2013; 131:1350-60. [PubMed: 23541327]

14. Tan BK, Zirkle W, Chandra RK, Lin D, Conley DB, Peters AT, et al. Atopic profile of patients failing medical therapy for chronic rhinosinusitis. Int Forum Allergy Rhinol. 2011; 1:88-94. [PubMed: 21731824]

15. Pearlman AN, Chandra RK, Chang D, Conley DB, Tripathi-Peters A, Grammer LC, et al. Relationships between severity of chronic rhinosinusitis and nasal polyposis, asthma, and atopy. Am J Rhinol Allergy. 2009; 23:145-8. [PubMed: 19401038]

16. Ramadan HH, Fornelli R, Ortiz AO, Rodman S. Correlation of allergy and severity of sinus disease. Am J Rhinol. 1999; 13:345-7. [PubMed: 10582111]

17. Robinson S, Douglas R, Wormald PJ. The relationship between atopy and chronic rhinosinusitis. Am J Rhinol. 2006; 20:625-8. [PubMed: 17181106]

18. Promsopa C, Kansara S, Citardi MJ, Fakhri S, Porter P, Luong A. Prevalence of confirmed asthma varies in chronic rhinosinusitis subtypes. Int Forum Allergy Rhinol. 2015

19. Kountakis SE, Arango P, Bradley D, Wade ZK, Borish L. Molecular and cellular staging for the severity of chronic rhinosinusitis. Laryngoscope. 2004; 114:1895-905. [PubMed: 15510011]

20. Lin DC, Chandra RK, Tan BK, Zirkle W, Conley DB, Grammer LC, et al. Association between severity of asthma and degree of chronic rhinosinusitis. Am J Rhinol Allergy. 2011; 25:205-8. [PubMed: 21819754] 
21. Rajan JP, Wineinger NE, Stevenson DD, White AA. Prevalence of aspirin-exacerbated respiratory disease among asthmatic patients: A meta-analysis of the literature. J Allergy Clin Immunol. 2015; 135:676-81. e1. [PubMed: 25282015]

22. Awad OG, Lee JH, Fasano MB, Graham SM. Sinonasal outcomes after endoscopic sinus surgery in asthmatic patients with nasal polyps: a difference between aspirin-tolerant and aspirin-induced asthma? Laryngoscope. 2008; 118:1282-6. [PubMed: 18475212]

23. Berges-Gimeno MP, Simon RA, Stevenson DD. The natural history and clinical characteristics of aspirin-exacerbated respiratory disease. Ann Allergy Asthma Immunol. 2002; 89:474-8. [PubMed: 12452205]

24. Laidlaw TM, Boyce JA. Pathogenesis of aspirin-exacerbated respiratory disease and reactions. Immunol Allergy Clin North Am. 2013; 33:195-210. [PubMed: 23639708]

25. Soyka MB, Wawrzyniak P, Eiwegger T, Holzmann D, Treis A, Wanke K, et al. Defective epithelial barrier in chronic rhinosinusitis: the regulation of tight junctions by IFN-gamma and IL-4. J Allergy Clin Immunol. 2012; 130:1087-96. e10. [PubMed: 22840853]

26. Pothoven KL, Norton JE, Hulse KE, Suh LA, Carter RG, Rocci E, et al. Oncostatin M promotes mucosal epithelial barrier dysfunction, and its expression is increased in patients with eosinophilic mucosal disease. J Allergy Clin Immunol. 2015; 136:737-46. e4. [PubMed: 25840724]

27. Seshadri S, Lin DC, Rosati M, Carter RG, Norton JE, Suh L, et al. Reduced expression of antimicrobial PLUNC proteins in nasal polyp tissues of patients with chronic rhinosinusitis. Allergy. 2012; 67:920-8. [PubMed: 22676062]

28. Tieu DD, Peters AT, Carter RG, Suh L, Conley DB, Chandra R, et al. Evidence for diminished levels of epithelial psoriasin and calprotectin in chronic rhinosinusitis. J Allergy Clin Immunol. 2010; 125:667-75. [PubMed: 20226301]

29. Van Crombruggen K, Vogl T, Perez-Novo C, Holtappels G, Bachert C. Differential release and deposition of S100A8/A9 proteins in inflamed upper airway tissue. Eur Respir J. 2016; 47:264-74. [PubMed: 26493794]

30. Hirschberg A, Kiss M, Kadocsa E, Polyanka H, Szabo K, Razga Z, et al. Different activations of toll-like receptors and antimicrobial peptides in chronic rhinosinusitis with or without nasal polyposis. Eur Arch Otorhinolaryngol. 2015

31. Ishida A, Ohta N, Suzuki Y, Kakehata S, Okubo K, Ikeda H, et al. Expression of pendrin and periostin in allergic rhinitis and chronic rhinosinusitis. Allergol Int. 2012; 61:589-95. [PubMed: 22918213]

32. Seshadri S, Lu X, Purkey MR, Homma T, Choi AW, Carter R, et al. Increased expression of the epithelial anion transporter pendrin/SLC26A4 in nasal polyps of patients with chronic rhinosinusitis. J Allergy Clin Immunol. 2015

33. Olze H, Forster U, Zuberbier T, Morawietz L, Luger EO. Eosinophilic nasal polyps are a rich source of eotaxin, eotaxin-2 and eotaxin-3. Rhinology. 2006; 44:145-50. [PubMed: 16792175]

34. Yao T, Kojima Y, Koyanagi A, Yokoi H, Saito T, Kawano K, et al. Eotaxin-1, -2, and -3 immunoreactivity and protein concentration in the nasal polyps of eosinophilic chronic rhinosinusitis patients. Laryngoscope. 2009; 119:1053-9. [PubMed: 19296494]

35. Van Zele T, Claeys S, Gevaert P, Van Maele G, Holtappels G, Van Cauwenberge P, et al. Differentiation of chronic sinus diseases by measurement of inflammatory mediators. Allergy. 2006; 61:1280-9. [PubMed: 17002703]

36. Van Bruaene N, Perez-Novo CA, Basinski TM, Van Zele T, Holtappels G, De Ruyck N, et al. Tcell regulation in chronic paranasal sinus disease. J Allergy Clin Immunol. 2008; 121:1435-41. 41 e1-3. [PubMed: 18423831]

37. Stevens WW, Ocampo CJ, Berdnikovs S, Sakashita M, Mahdavinia M, Suh L, et al. Cytokines in Chronic Rhinosinusitis: Role in Eosinophilia and Aspirin Exacerbated Respiratory Disease. Am J Respir Crit Care Med. 2015

38. Derycke L, Eyerich S, Van Crombruggen K, Perez-Novo C, Holtappels G, Deruyck N, et al. Mixed T helper cell signatures in chronic rhinosinusitis with and without polyps. PLoS One. 2014; 9:e97581. [PubMed: 24911279] 
39. Mahdavinia M, Carter RG, Ocampo CJ, Stevens W, Kato A, Tan BK, et al. Basophils are elevated in nasal polyps of patients with chronic rhinosinusitis without aspirin sensitivity. J Allergy Clin Immunol. 2014; 133:1759-63. [PubMed: 24636088]

40. Walford HH, Lund SJ, Baum RE, White AA, Bergeron CM, Husseman J, et al. Increased ILC2s in the eosinophilic nasal polyp endotype are associated with corticosteroid responsiveness. Clin Immunol. 2014; 155:126-35. [PubMed: 25236785]

41. Takabayashi T, Kato A, Peters AT, Suh LA, Carter R, Norton J, et al. Glandular mast cells with distinct phenotype are highly elevated in chronic rhinosinusitis with nasal polyps. J Allergy Clin Immunol. 2012; 130:410-20. e5. [PubMed: 22534535]

42. Nagarkar DR, Poposki JA, Tan BK, Comeau MR, Peters AT, Hulse KE, et al. Thymic stromal lymphopoietin activity is increased in nasal polyps of patients with chronic rhinosinusitis. $\mathrm{J}$ Allergy Clin Immunol. 2013; 132:593-600. e12. [PubMed: 23688414]

43. Zhang N, Van Zele T, Perez-Novo C, Van Bruaene N, Holtappels G, DeRuyck N, et al. Different types of T-effector cells orchestrate mucosal inflammation in chronic sinus disease. J Allergy Clin Immunol. 2008; 122:961-8. [PubMed: 18804271]

44. Van Zele T, Gevaert P, Holtappels G, van Cauwenberge P, Bachert C. Local immunoglobulin production in nasal polyposis is modulated by superantigens. Clin Exp Allergy. 2007; 37:1840-7. [PubMed: 17941912]

45. Hulse KE, Norton JE, Suh L, Zhong Q, Mahdavinia M, Simon P, et al. Chronic rhinosinusitis with nasal polyps is characterized by B-cell inflammation and EBV-induced protein 2 expression. $\mathrm{J}$ Allergy Clin Immunol. 2013; 131:1075-83. 83 e1-7. [PubMed: 23473835]

46. Kato A, Peters A, Suh L, Carter R, Harris KE, Chandra R, et al. Evidence of a role for B cellactivating factor of the TNF family in the pathogenesis of chronic rhinosinusitis with nasal polyps. J Allergy Clin Immunol. 2008; 121:1385-92. 92 e1-2. [PubMed: 18410958]

47. Patadia M, Dixon J, Conley D, Chandra R, Peters A, Suh LA, et al. Evaluation of the presence of B-cell attractant chemokines in chronic rhinosinusitis. Am J Rhinol Allergy. 2010; 24:11-6. [PubMed: 20109310]

48. Peters AT, Kato A, Zhang N, Conley DB, Suh L, Tancowny B, et al. Evidence for altered activity of the IL-6 pathway in chronic rhinosinusitis with nasal polyps. J Allergy Clin Immunol. 2010; 125:397-403. e10. [PubMed: 20159251]

49. Tan BK, Li QZ, Suh L, Kato A, Conley DB, Chandra RK, et al. Evidence for intranasal antinuclear autoantibodies in patients with chronic rhinosinusitis with nasal polyps. J Allergy Clin Immunol. 2011; 128:1198-206. e1. [PubMed: 21996343]

50. Tsybikov NN, Egorova EV, Kuznik BI, Fefelova EV, Magen E. Anticytokine autoantibodies in chronic rhinosinusitis. Allergy Asthma Proc. 2015; 36:473-80. [PubMed: 26534753]

51. Lan F, Zhang N, Zhang J, Krysko O, Zhang Q, Xian J, et al. Forkhead box protein 3 in human nasal polyp regulatory $\mathrm{T}$ cells is regulated by the protein suppressor of cytokine signaling 3 . J Allergy Clin Immunol. 2013; 132:1314-21. [PubMed: 23910692]

52. Pant H, Hughes A, Schembri M, Miljkovic D, Krumbiegel D. CD4(+) and CD8(+) regulatory T cells in chronic rhinosinusitis mucosa. Am J Rhinol Allergy. 2014; 28:e83-9. [PubMed: 24717938]

53. Nomura K, Obata K, Keira T, Miyata R, Hirakawa S, Takano K, et al. Pseudomonas aeruginosa elastase causes transient disruption of tight junctions and downregulation of PAR-2 in human nasal epithelial cells. Respir Res. 2014; 15:21. [PubMed: 24548792]

54. Malik Z, Roscioli E, Murphy J, Ou J, Bassiouni A, Wormald PJ, et al. Staphylococcus aureus impairs the airway epithelial barrier in vitro. Int Forum Allergy Rhinol. 2015; 5:551-6. [PubMed: 25821008]

55. Van Zele T, Gevaert P, Watelet JB, Claeys G, Holtappels G, Claeys C, et al. Staphylococcus aureus colonization and IgE antibody formation to enterotoxins is increased in nasal polyposis. $\mathrm{J}$ Allergy Clin Immunol. 2004; 114:981-3. [PubMed: 15480349]

56. Bachert C, Gevaert P, Holtappels G, Johansson SG, van Cauwenberge P. Total and specific IgE in nasal polyps is related to local eosinophilic inflammation. J Allergy Clin Immunol. 2001; 107:607-14. [PubMed: 11295647] 
57. Abreu NA, Nagalingam NA, Song Y, Roediger FC, Pletcher SD, Goldberg AN, et al. Sinus microbiome diversity depletion and Corynebacterium tuberculostearicum enrichment mediates rhinosinusitis. Sci Trans1 Med. 2012; 4:151ra24.

58. Aurora R, Chatterjee D, Hentzleman J, Prasad G, Sindwani R, Sanford T. Contrasting the microbiomes from healthy volunteers and patients with chronic rhinosinusitis. JAMA Otolaryngol Head Neck Surg. 2013; 139:1328-38. [PubMed: 24177790]

59. Ramakrishnan VR, Feazel LM, Gitomer SA, Ir D, Robertson CE, Frank DN. The microbiome of the middle meatus in healthy adults. PLoS One. 2013; 8:e85507. [PubMed: 24386477]

60. Oakley GM, Curtin K, Orb Q, Schaefer C, Orlandi RR, Alt JA. Familial risk of chronic rhinosinusitis with and without nasal polyposis: genetics or environment. Int Forum Allergy Rhinol. 2015; 5:276-82. [PubMed: 25677865]

61. Hsu J, Avila PC, Kern RC, Hayes MG, Schleimer RP, Pinto JM. Genetics of chronic rhinosinusitis: state of the field and directions forward. J Allergy Clin Immunol. 2013; 131:977-93. 93 e1-5. [PubMed: 23540616]

62. Mahdavinia M, Hsu J, Norton JE, Carter RG, Simon P, Siebert J, et al. Association of common filaggrin null mutations with atopy but not chronic rhinosinusitis. Ann Allergy Asthma Immunol. 2015; 114:420-1. [PubMed: 25747786]

63. Mahdavinia M, Suh LA, Carter RG, Stevens WW, Norton JE, Kato A, et al. Increased noneosinophilic nasal polyps in chronic rhinosinusitis in US second-generation Asians suggest genetic regulation of eosinophilia. J Allergy Clin Immunol. 2015; 135:576-9. [PubMed: 25312761]

64. Kim SJ, Lee KH, Kim SW, Cho JS, Park YK, Shin SY. Changes in histological features of nasal polyps in a Korean population over a 17-year period. Otolaryngol Head Neck Surg. 2013; 149:431-7. [PubMed: 23812744]

65. Katotomichelakis M, Tantilipikorn P, Holtappels G, De Ruyck N, Feng L, Van Zele T, et al. Inflammatory patterns in upper airway disease in the same geographical area may change over time. Am J Rhinol Allergy. 2013; 27:354-60. [PubMed: 23816657]

66. Lou H, Meng Y, Piao Y, Wang C, Zhang L, Bachert C. Predictive significance of tissue eosinophilia for nasal polyp recurrence in the Chinese population. Am J Rhinol Allergy. 2015; 29:350-6. [PubMed: 26219765]

67. Seshadri S, Rosati M, Lin DC, Carter RG, Norton JE, Choi AW, et al. Regional differences in the expression of innate host defense molecules in sinonasal mucosa. J Allergy Clin Immunol. 2013; 132:1227-30. e5. [PubMed: 23895899]

68. Peters AT, Spector S, Hsu J, Hamilos DL, Baroody FM, Chandra RK, et al. Diagnosis and management of rhinosinusitis: a practice parameter update. Ann Allergy Asthma Immunol. 2014; 113:347-85. [PubMed: 25256029]

69. Lund VJ, Flood J, Sykes AP, Richards DH. Effect of fluticasone in severe polyposis. Arch Otolaryngol Head Neck Surg. 1998; 124:513-8. [PubMed: 9604976]

70. Rudmik L, Schlosser RJ, Smith TL, Soler ZM. Impact of topical nasal steroid therapy on symptoms of nasal polyposis: a meta-analysis. Laryngoscope. 2012; 122:1431-7. [PubMed: 22410935]

71. Poetker DM, Jakubowski LA, Lal D, Hwang PH, Wright ED, Smith TL. Oral corticosteroids in the management of adult chronic rhinosinusitis with and without nasal polyps: an evidence-based review with recommendations. Int Forum Allergy Rhinol. 2013; 3:104-20. [PubMed: 22887970]

72. Hopkins C, Andrews P, Holy CE. Does time to endoscopic sinus surgery impact outcomes in chronic rhinosinusitis? Retrospective analysis using the UK clinical practice research data. Rhinology. 2015; 53:18-24. [PubMed: 25756073]

73. Bhattacharyya N. Influence of polyps on outcomes after endoscopic sinus surgery. Laryngoscope. 2007; 117:1834-8. [PubMed: 17690616]

74. Young J, Frenkiel S, Tewfik MA, Mouadeb DA. Long-term outcome analysis of endoscopic sinus surgery for chronic sinusitis. Am J Rhinol. 2007; 21:743-7. [PubMed: 18201458]

75. Stevens WW, Peters AT, Grammer LC III, Hulse KE, Kato A, Tan BK, et al. Clinical Characteristics of Aspirin Exacerbated Respiratory Disease in a Tertiary Care Patient Cohort. J Allergy Clin Immunol. 2016; 137:AB65. 
76. Forwith KD, Chandra RK, Yun PT, Miller SK, Jampel HD. ADVANCE: a multisite trial of bioabsorbable steroid-eluting sinus implants. Laryngoscope. 2011; 121:2473-80. [PubMed: 22020898]

77. Marple BF, Smith TL, Han JK, Gould AR, Jampel HD, Stambaugh JW, et al. Advance II: a prospective, randomized study assessing safety and efficacy of bioabsorbable steroid-releasing sinus implants. Otolaryngol Head Neck Surg. 2012; 146:1004-11. [PubMed: 22301107]

78. Kennedy DW. The PROPEL steroid-releasing bioabsorbable implant to improve outcomes of sinus surgery. Expert Rev Respir Med. 2012; 6:493-8. [PubMed: 23134241]

79. Han JK, Marple BF, Smith TL, Murr AH, Lanier BJ, Stambaugh JW, et al. Effect of steroidreleasing sinus implants on postoperative medical and surgical interventions: an efficacy metaanalysis. Int Forum Allergy Rhinol. 2012; 2:271-9. [PubMed: 22550039]

80. Han JK, Forwith KD, Smith TL, Kern RC, Brown WJ, Miller SK, et al. RESOLVE: a randomized, controlled, blinded study of bioabsorbable steroid-eluting sinus implants for in-office treatment of recurrent sinonasal polyposis. Int Forum Allergy Rhinol. 2014; 4:861-70. [PubMed: 25266981]

81. Gevaert P, Calus L, Van Zele T, Blomme K, De Ruyck N, Bauters W, et al. Omalizumab is effective in allergic and nonallergic patients with nasal polyps and asthma. J Allergy Clin Immunol. 2013; 131:110-6. e1. [PubMed: 23021878]

82. Gevaert P, Van Bruaene N, Cattaert T, Van Steen K, Van Zele T, Acke F, et al. Mepolizumab, a humanized anti-IL-5 mAb, as a treatment option for severe nasal polyposis. J Allergy Clin Immunol. 2011; 128:989-95. e1-8. [PubMed: 21958585]

83. Bachert C, Mannent L, Naclerio RM, Mullol J, Ferguson BJ, Gevaert P, et al. Effect of Subcutaneous Dupilumab on Nasal Polyp Burden in Patients With Chronic Sinusitis and Nasal Polyposis: A Randomized Clinical Trial. JAMA. 2016; 315:469-79. [PubMed: 26836729]

84. Busse W, Corren J, Lanier BQ, McAlary M, Fowler-Taylor A, Cioppa GD, et al. Omalizumab, anti-IgE recombinant humanized monoclonal antibody, for the treatment of severe allergic asthma. J Allergy Clin Immunol. 2001; 108:184-90. [PubMed: 11496232]

85. Ortega HG, Liu MC, Pavord ID, Brusselle GG, FitzGerald JM, Chetta A, et al. Mepolizumab treatment in patients with severe eosinophilic asthma. N Engl J Med. 2014; 371:1198-207. [PubMed: 25199059]

86. Wenzel S, Ford L, Pearlman D, Spector S, Sher L, Skobieranda F, et al. Dupilumab in persistent asthma with elevated eosinophil levels. N Engl J Med. 2013; 368:2455-66. [PubMed: 23688323] 

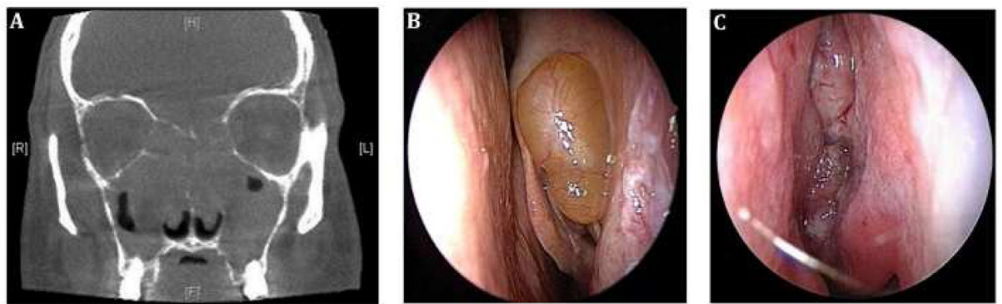

Figure 1. Imaging studies of nasal polyps

Sinus CT scan of a patient with CRSwNP (A). Benign (B) and malignant (C) nasal polyps are directly visualized in the nasal cavity by endoscopy. 
1

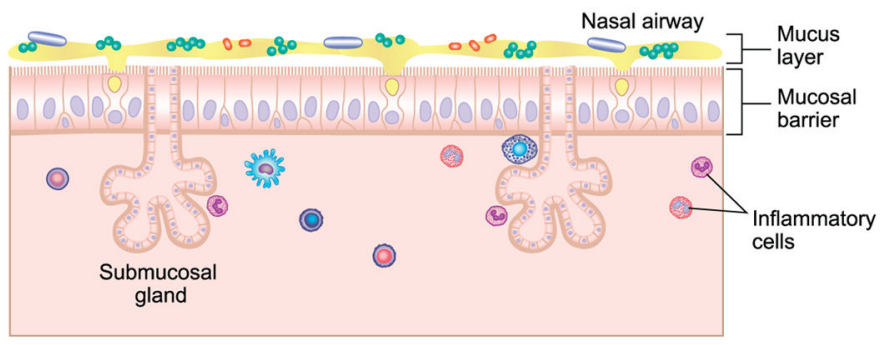

Normal nasal mucosa and colonization with microbes
2

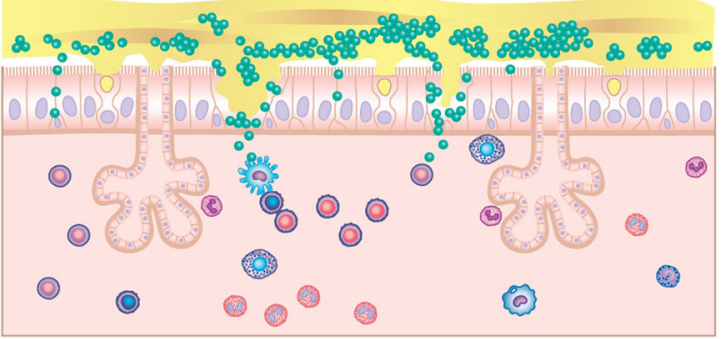

Loss of barrier with increased abundance and decreased diversity of microbes

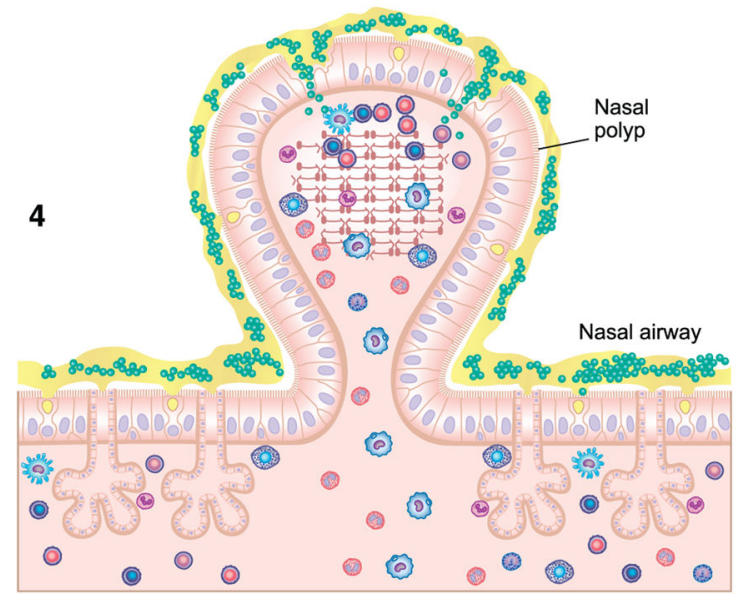

Tissue remodeling with loss of submucosal glands in polyp and profound inflammatory cell expansion
Recruitment and expansion of inflammatory cells, tissue swelling,

inflammation, and deposition of crosslinked fibrin

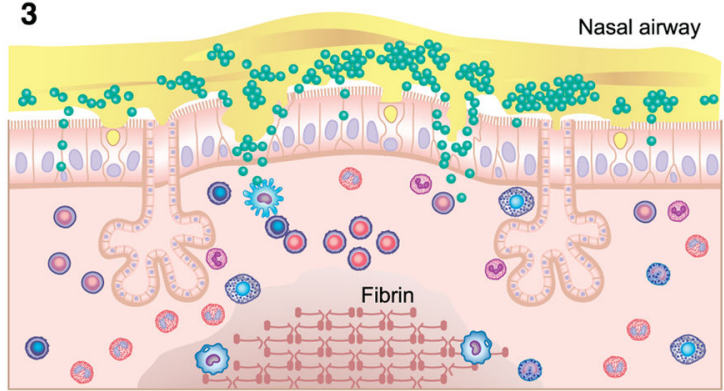

Figure 2. Overview of CRSwNP pathogenesis

Colonization with microbes and accumulation of immune cells can lead to tissue injury, inflammation, and mucosal barrier loss in CRS. 